\title{
Emotional policies: Introducing branding as a tool for science diplomacy
}

\author{
Alexander Raev $\mathbb{1}^{1 凶} \&$ Ellen Minkman ${ }^{2 凶}$
}

This article seeks to expand the science diplomacy (SD) discourse by introducing the concept of branding, focusing on its use as a tool for nation state decision makers. Although the current literature on SD has explored the relation between science and diplomacy, the question of how individual science projects can effectively aid SD has been left largely unanswered. Drawing on the SD as well as on the place and policy branding literature, a framework for the analysis and conceptualization of branding as a tool for SD and for Public Diplomacy in general is developed. This framework introduces three distinct branding styles: nation branding, policy branding and policy tool branding. The applicability of the framework is demonstrated by the comparison of two cases of branding by nation state policy makers: branding in the field of German transnational education and in the science and knowledgebased Dutch Water Diplomacy. The German case study shows that branding activities relating to 'German' SD are fragmented and focus mostly on individual projects, while the use of transnational education as an instrument to advance policy branding or nation branding remains largely underdeveloped. Such a lopsided branding process undermines the effectiveness of branding as an effective SD tool. In contrast, the potential of coordinated branding strategies as a foreign policy tool becomes apparent in the 'Dutch Delta Approach'. In this centralised and coordinated branding process, activities on all three proposed branding layers were implemented, effectively employing branding to increase the visibility of the Dutch nation state, increase the attraction of its high-tech water management sector as well as to rejuvenate the Netherland's bi-lateral relations with selected partner countries. Branding, as we argue, should be added to the analysis of contemporary science diplomacy as well as of broader foreign policies, adding to the understanding of SD as an instrument of cross-border communication and global opinion shaping. The paper ends with a discussion of potential limitations of branding, in order to illustrate that branding can be an effective instrument but should not be seen as an international relations panacea.

\footnotetext{
${ }^{1}$ Institute of Political Science, University of Tübingen, Tübingen, Germany. ${ }^{2}$ Faculty of Technology, Policy and Management, Delft University of Technology,

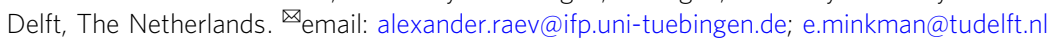




\section{Diving into the world of soft power}

W hile academic interest in the linkages between science and diplomacy is returning to prominence (Gluckman et al., 2017; Penca, 2018; Rungius, 2018), the question of how science projects and policies can effectively aid science diplomacy (SD) seems to have been left largely unanswered ${ }^{1}$. In this article we aim to contribute to the SD discourse by introducing the concept of branding (e.g. Eshuis and Klijn, 2012; Marsh and Fawcett, 2011), focussing on its use as a tool, employed to actively influence various audiences' perceptions of nation states. We draw on newer SD research, adding questions regarding strategic aims, national needs, as well as emerging global challenges in general (Berg, 2010; Gluckman et al., 2017) and more recently and specifically to global health crises (Šlosarčik et al., 2020) to the SD discourse, pre-empting the currently on-going COVID-19 crisis. These questions and policy maker's responses to them bring new actors beyond the representatives from the Ministries of Foreign Affairs into the spotlight. Those actors often include ministries, state and quasi-state agencies and even non-governmental actors outside the usual foreign policy sphere, that were hitherto only domestically active (Berg, 2010, p. $71)^{2}$. Therefore, new tools to further SD agendas become visible, which now need to be conceptualized and analysed. In this paper, we seek to connect the field of SD to the use of one specific tool, namely branding. Although branding, understood here as a deliberate process of adding emotional meaning to political phenomena, has been associated with the broader public diplomacy discourse before by few authors (e.g. Szondi, 2008), there have been - to our knowledge-no studies on the question of how branding activities are being used in SD. Hence we explore the added value of and limitations of branding for achieving SD objectives.

Previous studies have focussed on nation branding as means to enhance international relations (Dinnie, 2016; Szondi, 2008; Grincheva, 2020), to boost the attractiveness of their country as a tourist destination (Eshuis and Klijn, 2012), or to create support for (foreign) policies (Greenwald, 2018; Mohammadzadeh, 2017). The latter category has previously been described as "soft power" (Nye, 2004), but is increasingly known by more differentiated terms such as "Cultural Diplomacy" (for the emerging cultural policies of the Gulf states, see e.g. Ajan, 2015; Grincheva, 2020), "science diplomacy" (e.g. Flink and Schreiterer, 2010; Turekian, 2018) or even by terms as specific as "Water Diplomacy" (Van Genderen and Rood, 2011), "Sports Diplomacy" (Murray, 2018) or "Global Health Diplomacy" (Kevany, 2014; Šlosarčik et al., 2020). ${ }^{3}$ The lack of research into how branding can aid SD and other types of 'soft' diplomacy is surprising, especially as the fields of science and education have increasingly been connected to issues of internationalization, marketization, and profit orientation (Kwiek, 2013; Schulze-Cleven and Olson, 2017). This brings the issue of reputation of scientific institutions and whole national science sectors to the fore of nation state science and education policy making (Altbach, 2015; Knie and Simon, 2016, p. 21; Schütte, 2008).

At the same time, cross border science and higher education projects and here especially projects of transnational education (TNE), have increasingly been integrated into policy fields as diverse as (international) economic policy, international relations and development policy (Fromm and Raev, 2018; Ziguras and McBurnie, 2015). Branding, as we will argue, can serve as one of the tools at the disposal of national states to more effectively align their science and education sectors with their various (foreign) policy agendas. Also, branding can be used to strengthen the visibility and attractiveness of science and education projects, as well as whole science and education sectors.

Although the term branding, understood as "a set of practices and tools designed to generate a positive image of [a] product"
(Gienow-Hecht, 2019, p. 756) originated in the field of marketing, it has become an integral part of various policy and political processes. Branding has been so far used to boost the visibility and images of politicians, political parties, places and nations and even policies (Basu and Wang, 2009; Dinnie, 2016; Donner et al., 2017; Minkman and Van Buuren, 2019; Speed et al., 2015; White, 2002).

The objective of this paper is therefore to create a framework of analysis of branding in SD and foreign policy in general. This is done in order to explore how branding could enrich analyses of SD and, hereby, highlight a previously overlooked part of the toolbox of Science Diplomats. Doing so, we are not only broadening the scope of analysis, but shift the frame through which we observe SD. We seek to add two new research questions to the SD framework. Firstly, we ask, who is actually targeted by specific SD activities? And secondly, how do SD activities reach and influence different target audiences?

\section{Theoretical deduction of a three-layered framework on branding}

Introducing branding to SD. Until recently, SD literature focused either on the question of what SD was (Fähnrich, 2013; Flink and Schreiterer, 2010) and on how it was done (Schütte, 2008). Current literature has an expanded scope, focussing on strategic aims (Gluckman et al., 2017) as well as on the question of who actually influences SD (Tourekian et al., 2014, p. 3). SD then can be described as "aspiration[s] by larger [influential] countries to project their culture and influence beyond their boundaries" (Gluckman et al., 2017, p. 5) by "us[ing] science and innovation to project their national interests" (Gluckman et al., 2017) in order to "assert[...] themselves on a global stage and [to] increase[e] their relevance to international policy discussions (Gluckman et al., 2017). This rather broad definition adds to the SD discourse science organizations in a narrow sense as well as science and knowledge-based actors from outside academia. As we look at SD from the perspective of Science for Diplomacy in which science is used to improve international relations (see The Royal Society and AAAS, 2010, p. 11), the question arises, how science-based projects can be used to further nation states' diplomatic interests. To answer this question, we propose to include aspects of symbolic communication and its "meaning and value" (Kapferer, 1992 in Eshuis and Klijn, 2012, p. 6) to the general discourse on SD, hence adding the issue of emotion to an otherwise rational policy process.

At the same time, both brands and branding activities can take various forms, used to create different images in different policy fields. In order to structure the varying forms of branding and brands in the context of SD, we seek to differentiate between three layers of branding: (1) policy tool branding, (2) policy branding, and (3) place branding (Dinnie, 2016; Eshuis and Klijn, 2012; Szondi, 2008).

Introducing a framework on branding. Before we can move to describe branding as a tool for SD, we need to define the term itself. For this article we understand branding as a communicative process whereby "meaning and value" (Kapferer, 1992 in Eshuis and Klijn, 2012, p. 6) or in other terms a unique identity (Drori et al., 2016, p. 164) is given to an organization or a phenomenon, hence defining "and differentiat[ing] it from similar phenomena by adding particular meaning to it" (Eshuis and Klijn, 2012, p. $6)^{4}$. Often a meaning, so our argument, is given not by means of facts but by an appeal to emotional aspects of the communication process between a sender and an audience. A brand then is understood as "a sign with a denotative function that identifies an object, and a connotative function that evokes associations 
through which an object is imbued with meaning" (Eshuis and Klijn, 2012, p. 15). We therefore understand branding as a creative tool used by policy makers to imbue different audiences with positive understandings (meanings) and positive dispositions (emotions) towards individual projects, national policy sectors as well as towards nation states as a whole. Therefore the branding of science policies and of specific scientific projects is put into a shared context with attempts at producing a "strategic selfpresentation $[\ldots]$ with the aims of creating reputational capital [...] at home and abroad" (Szondi, 2008, p. 5). Seen from this perspective, a brand can be understood as a symbol that has both tangible and intangible aspects. Tangible aspects are the branded objects themselves, such as organizations, places, people, or specific policies (e.g. Eshuis and Klijn, 2012; Speed et al., 2015; White, 2002). The intangible part of a brand on the other hand consists of the positive associations that the brand is supposed to invoke. In other words, a brand consists of a specific object and of all associations connected to it. Multiple, often co-existing associations form an emotive associative network (Govers, 2011; Zenker and Braun, 2017). Individual associations within this network may relate to different aspects of the branded object or to varying brand expectations of different audiences ${ }^{5}$. Therefore, outcomes of meaning-making processes may differ from what was intended by the brand creator, as brands are prone to unintentional (and sometimes unwanted) associations, given to it by both targeted and initially not targeted audiences. Brand outcomes may be even further complicated, as "multiple political discourses and diplomatic narratives collide and overlap" (Grincheva, 2020, p. 90) over brands in the political sphere 6 . Therefore, successful brands are often coordinated by so-called brand managers (see here Temporal, 2015, p. $141 \mathrm{ff}$ ). Brand managing may involve various strategies and tactics (see here Szondi, 2008, p. 17 ff). They include the use of visual symbols and slogans, the creation and maintenance of cognitive associations and the creation of meaningful images to challenge unintended perceptions regarding branded objects. Branding thereby equals a form of persuasive and often symbolic communication, whereby the underlying logic is emotional rather than rational (Eshuis and Klijn, 2012; Marsh and Fawcett, 2011; Papadimitriou et al., 2015). Equalling branding to a form of communication implies that there are several actors involved, namely the sender who creates and conveys the brand and a designated audience (Lynch and De Chernatony, 2004). In order to describe the possible use of branding as a tool for $\mathrm{SD}$, we propose three different, yet interconnected layers of branding which need to be taken into consideration.

Place branding. The perhaps best known layer of branding in the sphere of policy making relates to images of geographical places, such as cities, regions, or nation states (Donner et al., 2017; Eshuis and Klijn, 2012). Place branding is often used to increase the visibility of a geographical place, beyond its own borders. It usually aims at enhancing a territories' reputation regarding a global audience or to attract visitors (e.g. tourists, students, researchers) (Eshuis and Klijn, 2012) ${ }^{7}$. In terms of entire nation states, branding can be understood as "simply a new term for image management" (Szondi, 2008, p. 3). The United Arab Emirates, Qatar, and Singapore have for the last years used especially higher education policies to improve their countries' image as open and science-oriented. By attracting foreign university providers to establish branch campuses, the three countries have tried to re-invent themselves as so-called International Education Hubs (Knight, 2011), attempting the creation of an image of open-mindedness and innovation.

Policy branding. A second layer of branding consists of a specific policy that is branded. Branded policies are usually tied to a certain policy field, such as foreign policy or the social or public health domain (Ogden et al., 2003). Using the device of policy branding, policy makers on the domestic policy arena try, so our argument, to enhance the visibility as well as the legitimacy of new or reformed policies in order to imbue them with positive emotions to gain the support of relevant stakeholders and eventually, of voters. Policy branding seems to be used especially in fields, where public policy campaigns "have become increasingly 'infused with brand attributes so that the target audience is able to experience the "product" and its value" (Marsh and Fawcett, 2011, p. 520). This means, the branding process "is typically linked to programmatic success" (Marsh and Fawcett, 2011, p. 521) and usually includes "a policy package that [is] simple and marketable to policy makers and programme implementers" (Marsh and Fawcett, 2011, p. 184). Unfortunately, the research of policy branding is still relatively underdeveloped. Therefore, helpful examples are scarce. However, one example of a successful policy branding was the promotion of business improvement districts (BIDs), a new governance mode to revitalize downtown areas through public-private partnerships. This policy model emerged in Vancouver in the 1970s and was actively promoted around the world (McCann and Ward, 2014). In principle however, most, if not all, existing policies can be branded.

Policy tool branding. As a third layer we propose to focus on the branding of specific policy tools, which should be understood here as tangible products offered by policy makers to various 'consumers' and audiences ${ }^{8}$. Policy tool branding can occur both on a domestic as well as on a global level and usually comes in forms of tangible policy outputs. It should be added, that similar policy tools, especially science or education projects and connected to them similar branding strategies can be used by different actors as "particular tools impart similar pressures and have similar operating requirements wherever they happen to be applied" (Salamon, 2000, p. 1643). Hence it should come as no surprise, that actors from different policy fields can be observed to make use of similar branding strategies, especially in the field of official foreign relations, which in many countries are being operated by competing nation state organizations that are active in different policy fields. In order for a broader policy to be attractive across national borders, policy tools need to be communicated and defined in terms of a brand (Marsh and Fawcett, 2011, p. 521), hence as a process which "refers to the devices that serve to identify, express, and share the meaning of the product with consumers" (Basu and Wang, 2009, p. $81 \mathrm{ff}$ ) and finally managed, in terms of "the different ways in which organizations are structured in order to promote, protect, and sustain the brand" (Marsh and Fawcett, 2011, p. 521). Structurally similar policy tools can, as we will show, be used to address different aspects within the larger contexts of SD and foreign policy. Depending on the use of different strategies, this branding layer has the potential to address various audiences, promoting various different policy aims, depending on the branding actors and their underlying policy agendas.

Purposes of branding. In addition to the introduction of different branding layers, this paper is concerned with the question of why policy makers on the nation state level engage in branding.

The branding literature pointed out the possibility of boosting or re-inventing existing reputations on a nation-state level (Marsh and Fawcett, 2011; McCann, 2013). Instead of highlighting military aspects of international relations, public relations have become more important in public diplomacy (Jansen, 2008; Stone, 2020, p. $10 \mathrm{ff}$ ), reflecting new and complex political realities after the end of the Cold War as well as the rapid 
technological developments over the last 30 years (Grincheva, 2020 , p. 95). Hence, modern media as well as mass mobility have made other previously distant countries more accessible, thereby increasing opportunities for reputation management on a global level (Ajan, 2015). Simultaneously, new challenges (e.g. climate change, global terrorism, or lately public health crises) have moved to the centre of attention of public diplomacy makers (Hocking, 2006, p. 20). Not surprisingly, public diplomacy has in the last years been increasingly involved in trying to steer developments in these sectors for (geo)political reasoning. As such, branding can be used to draw attention to a particular issue, thereby constituting a specific form of agenda setting (Ogden et al., 2003).

A second reason for branding is to differentiate branded objects from similar objects employed by competitors (Braun, 2012, p. 265). Although originating in economic thinking, differentiation occurs whenever similar objects, understood as purchasable products, are compared to each other. Hence, objects as diverse as whole nation states or policy tools like cross-border study programmes can be branded, if they are competing with other nation states or cross-border study programmes for global attention or reputation. Therefore, branding can be said to be driven by the ambition to build a support base for a particular object, whether this support materializes in the form of investments, students willing to pay for access to internationalized higher education institutions or as tourists visiting one country and not another (Dinnie, 2016).

How branding is done. No two branding processes by state actors are the same, making it hard to compare different branding activities (Eshuis and Klijn, 2012). However, the current branding literature seems to agree on certain necessary ingredients needed to create 'effective' brands, i.e. brands that are likely to establish the intended associations policy makers connect to them. Overall, the policy-related branding literature pointed out that a 'strategic brand framework' is needed in order to create an effective brand (Govers, 2011; Zenker and Braun, 2017). Such a framework consists of much more than just a logo, slogan or promotion of a single product and should incorporate the created brand in a longer-term vision or strategy so that it supports the underlying political priorities of the policy maker. We acknowledge the importance the target audience's brand perception as well as the question to what degree branding contributes to the achievement of objectives it is connected to, but we limit ourselves in this framework to the question of brand development. As brand reception is a complicated process, taking place at a diverse set of audiences (Temporal, 2015, p. 149), it should be considered a distinct process, which should be regarded elsewhere ${ }^{9}$.

The process of brand creation. Branding activities usually start with the process of brand definition (Basu and Wang, 2009). An effective brand typically includes a number of ingredients, which need to be in place: an object that is branded, a target audience and actors that are responsible for communicating the brand (Temporal, 2015, p. 149). Successfully branded objects tend to be carefully identified and detached from their original context (Czarniawska and Joerges, 1996) in order to allow for the formulation of more generalized messages suitable to specific audiences. Therefore, market research as well as marketing intelligence were seen as indispensable to identify target audiences for the brand (Eshuis and Klijn, 2012; König and König, 2012). Authors further stressed the importance of involving the 'brand community' (i.e. all actors that are involved in the branded product or service) in the process of brand definition in order to create brand images that would appear genuine and credible
(Eshuis and Klijn, 2012; Zenker and Braun, 2017). Effective brands often incorporate all core values, distinguishing the brand from similar competing brands, and incorporate the values of the products, of services and of the policy sector behind it (Donner et al., 2017). The integration of a brand into its larger political context was seen as another important ingredient for a robust brand. Integration included the linkage of branded objects to long-term visions, political objectives, or existing programmes (Zenker and Braun, 2017).

Another possibility is the connection of a newly developed brand to other already existing and related brands managed by the same actors (Zenker and Braun, 2017). As such, layered images of brands emerged, whereby brands developed for a specific purpose could be built on top of other branded layers. For example, German actors within the German TNE sector tried to connect TNE-projects to the brand "Higher Education Made in Germany" 10 making use of the already existing image of a strong and innovative German science and technology sector (Kathöfer, 2013, p. 19).

Apart from brand definition and from target audience identification, brands were seen to be in need of brand communication in order to maintain functioning brands. The most important ingredient here was the alignment of communication activities targeting different (brand) stakeholders (Eshuis and Klijn, 2012; Temporal, 2015, pp. 149-151). The communication of policy brands was understood as a repeated process of 'story telling', based on a limited number of examples (McCann, 2013). As such, it was deemed important that a majority of involved stakeholders (e.g. policy makers and organizations involved in setting up that, which is branded) had interpreted the brand in the same way (Zenker and Braun, 2017). In addition, effective brands were understood as making use of windows of opportunities, generating public media attention to express the brand identity and add credibility to its claims (Kavaratsis and Hatch, 2013).

In order to maintain established brands and to ensure their effectiveness, authors have stressed the importance of brand managers in all phases of the branding process (Temporal, 2015, pp. $147 \mathrm{ff}$ ). Brands were seen as being continuously in need of coordination. This coordination included activities of brand network maintenance as well as of an aligned audience communication in order to keep the brand up to date (Eshuis and Klijn, 2012; Govers, 2011). Perceived brand management activities could range from organizing events where the brand would be celebrated, to freeing up resources to sustain brand communications and develop marketing vehicles. Depending on the nature of the brand as well as on the size of stakeholder networks, brand managers could both be individuals as well as whole organizations, tasked with providing brand maintenance support (Fig. 1).

Limitations of an effective brand. Even when a brand has been sufficiently planned, established, and communicated to target audiences and even if the process of brand management has been effective, limitations to the process of branding exist.

A first important limitation to effective brands is the possibility that reputations outgrow underlying capacities. This type of limitation refers to an "image-reality gap", whereby the delivered products and goods cannot live up to the expectations regarding quality, quantity, or availability of the branded objects (Donner et al., 2017; Eshuis and Klijn, 2012). Such gaps may result in a brand losing its credibility and hence threaten the existing congruent, positive brand association, endangering not only the branded product or products but the branding organization as well. This specific brand risk is more likely to occur with brands 


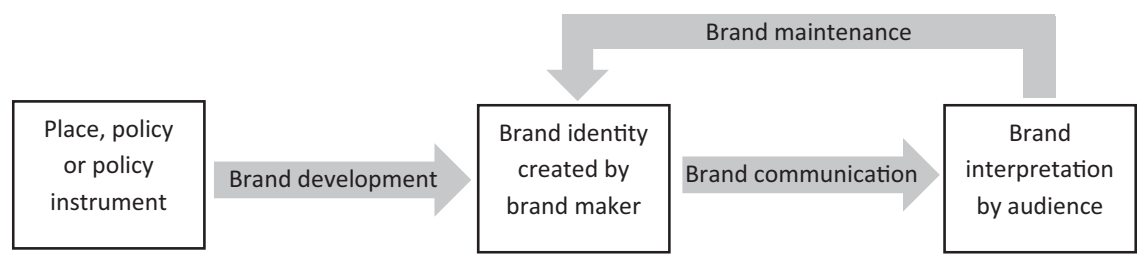

Fig. 1 Visualization of branding. Rectangles represent the three levels of branding, while arrows indicate the processes of transitioning between the levels. Figure based on Minkman and Van Buuren (2019) and Basu and Wang (2009).

that create associations of outstanding quality (Donner et al., 2017). To create a brand, branded objects are often simplified and integrated into limited narratives (Drori et al., 2016, p. $164 \mathrm{ff}$ ), based on a limited number of examples (McCann, 2013), often constructed out of different textual, material, or visual vestiges (Drori et al., 2016). In the sector of SD, this kind of brand limitation can occur, when science is exploited for political purposes (Flink and Schreiterer, 2010). In the previous subheading we mentioned that effective brands are linked to political objectives. However, when claims of quality or competence are exaggerated for political purposes, they might reduce a brand's authenticity, e.g. when a research project is not able to deliver promised results or when an education institution does not deliver the promised teaching quality.

A second and related limitation is that of information overload (Zenker and Braun, 2017), whereby a brand is seen to cover too much content for the target audiences to grasp. An effective brand needs congruent associations and should encompass various elements, ranging from an explicit connection to specific policy goals to concrete marketing elements such as slogans and logos. An over-complex brand image risks that target audiences misinterpret the actual brand, because they only selectively absorb information to simplify the brand (Zenker and Braun, 2017). Examples of over-complex brands can occur, when a brand has too many elements, e.g. too many different products under one name or it can be over-complex, when too much meaning is integrated into brand messages like slogans or logos.

The final limitation concerns the governance structure of a brand, consisting of the responsibility for brand maintenance and orchestrating cooperation (Eshuis and Klijn, 2012; Zenker and Braun, 2017). Both in SD and branding, there may be confusion over who is responsible for a branding process (Basu and Wang, 2009; Flink and Schreiterer, 2010). This confusion often was caused by a too large or diverse set of brand stakeholders and an unclear distribution of competencies and responsibilities. On the one hand, authors agreed on the importance of a rather hierarchical actor arrangement implementing the necessary tasks of the brand management. On the other hand, especially in fields like SD the different stakeholders need to be voluntarily involved in branding processes, as their resistance might weaken or even endanger the success of branding activities (Eshuis and Klijn, 2012).

\section{Selection of cases for a practical application}

The use of case studies. Given the limited number of studies on branding as a policy tool for SD, we adopted an explorative case study approach, comparing two science-based branding processes that differed mainly in their efficiency. We took a branding process in the field of transnational higher education (TNE; for a discussion on the German field of TNE, see Fromm and Raev, 2020) as the main case to study, embedding it in the Science for Diplomacy stream of the current SD discourse. The case of German TNE has been selected in order to display possibilities and challenges of branding within the field of SD, as it offers a wide variety of state funded cases, ministerial actors and changing policy aims. We contrasted this German case with the example of an effective, coordinated branding process in the field of knowledge and science-based diplomacy: the Dutch Delta Approach (DDA).

Data collection and analysis. For both cases we relied on existing datasets that were collected in two dissertation projects, focussing on two science and knowledge-based fields; German TNE and 'the DDA'11. The TNE-dataset consisted of publicly available documents published by the relevant ministries and intermediary organizations (including 28 strategy plans, 6 official websites, and 577 media interviews and public speeches) and 14 expert interviews held by the first author. For the second case we reinterpreted an existing dataset of 40 Dutch national government policy documents and 120 semi-structured interviews with 100 different individuals, including Dutch policy makers (private sector) experts and academics as well as policy makers and local experts in targeted countries.

Introducing the cases. In the last 30 years, the German government with the help of German universities has initiated, funded, and supported the establishment of more than 74 longterm cross-border higher education projects, which currently educate more than 35,000 students in over 34 countries (DAAD and DZHW, 2018) ${ }^{12}$. These higher education institutions included 14 large bi-lateral German Universities, 8 so-called Centers of Excellence, and at least 16 German institutes and faculties as well as around 30 individual study programmes at foreign partner universities (see here Fromm and Raev, 2020). In difference to other TNE-sectors, most of Germany's TNE-projects have been established under the tutelage of three federal ministries, the Federal Foreign Office, the Federal Ministry of Education and Research as well as the Federal Ministry for Economic Cooperation and Development (Fromm and Raev, 2020). Hence, the German TNE-sector fulfils policy aims in the field of foreign policy, higher education policy and development policy ${ }^{13}$. Although, the field of German TNE was seen as a successful endeavour that was celebrated by the German government, all major political parties and the German university sector, there has been no discernible branding strategy spanning the entire field of TNE.

In contrast, Minkman and Van Buuren (2019) demonstrated how a purposeful branding campaign led to the creation of an effective science and knowledge-based brand: the science-based 'DDA'. The Dutch economy is highly knowledge-driven and since 2012, the Dutch government invested in branding its water expertise as part of an international strategy (Topsector Water, 2013), highlighting further the power of expert knowledge of the Dutch Water sector. We are aware that knowledge-driven economies are broader than SD, but consider this case a relevant comparison to the German TNE for two reasons. First, scientific knowledge is at the base of the domestic Delta Approach in the Netherlands. Second, the branding campaign played a key role in Dutch foreign policy and formed an important basis for maintaining its bi-lateral relations with key partners. In the last 
decade, a comprehensive and successful branding strategy was developed, targeting mainly foreign state actors (Minkman and Van Buuren, 2019). We argue, that this state-led branding makes the DDA an interesting case to illustrate how the tool of branding in a science-based policy field could be successfully used.

\section{Results of the practical application of the framework Layers of the brand}

Place branding. Since its reunification, the German government established higher education projects abroad to portray Germany as a nation of science and innovation (Fromm and Raev, 2020), summarized in the brand slogan "Wissenschaftsstandort Deutschland" (Science Location Germany). Under this slogan, two federal ministries, the Federal Foreign Office and the Federal Ministry of Education and Research, have previously funded various projects at home and abroad with the aim of increasing the visibility of Germany as a science nation (Auswärtiges Amt, 2013). Those activities had, however, overlapping and partially contradictory aims, indicating a lack of policy coordination. Although representatives of those federal ministries mentioned in interviews that German TNE was part of their "toolbox" for branding the German Science Sector, German TNE-projects are established independently by German university consortia (see here DAAD, 2012, p. 8), while the ministries provide the necessary funding. Although the connection of TNE-projects to Germany was given, when "at least the brand 'Higher Education Made in Germany' was discernible” (Kathöfer, 2013, p. 9), manifested through German lessons, exchange programmes to Germany or following Humboldt's principle of uniting teaching and research (Kathöfer, 2013), the connection to the German Science Sector remained weak. Logos of many German TNEprojects do not include a German flag or other national symbol, while their names and logos are often not visible on their German partner universities' publication. German universities are likewise only faintly represented on the various TNE-project's publications, especially on their websites. Therefore, for most audiences, the connection of individual TNE-projects to the German Science Sectors remains rather obscure.

In contrast to Germany's Science Sector, we observed that the Dutch government actively connected the brand surrounding its international delta management activities to existing elements of a water-focused place brand. Water is closely tied to the geography and national pride of the Netherlands, which is illustrated by slogans like "Nederland, waterland" ("Netherlands, land of water") and "God created the world, but the Dutch created the Netherlands". These slogans are actively used by the Dutch government, the tourist industry and private businesses alike (see e.g. Holland.com, n.d.; Rijksoverheid, 2018), hinting at an aligned branding identity of the different actors. In 2009 the Dutch government went even further and selected five deltaic countries for collaboration regarding climate change, the Millennium Development Goals and enhancing trade. It committed itself to developing "an international marketing programme" to position the Dutch water and delta sector internationally (Rijksoverheid, 2008, p. 9). Hence, individual policy activities were strategically linked to both the existing image of the Netherlands and to its scientific and engineering sectors.

Policy branding. In the case of German TNE, we did not observe any coordinated branding activities on the policy level. In the past, there was no overarching policy (and thus branding process), which would have been able to cover the hitherto separate activities of the three ministries funding the German TNE sector (see Fromm and Raev, 2018). Rather, they seemed to pursue individual policy aims, thereby diluting the branding efficiency of TNE as a coordinated policy approach. Rather than charging TNE-policies with a coherent and unified emotive meaning, contents of foreign policy, internationalization policy, and development policy were communicated as policy aims of the individual ministries. Instead of actively targeting audiences abroad, policy branding was used to gain advantages in a domestic competition for competencies within the German political system, especially between the Foreign Office and the Federal Ministry of Education and Research.

While the German case had two separate target audiences, the branding of the DDA was solely aimed at policy makers and highlevel politicians abroad. Like in the German case, three ministries were involved, in this case the Ministry of Economic Affairs, the Ministry of Infrastructure \& Environment and the Ministry of Foreign Affairs (including their minister for Foreign Trade \& Development Cooperation) ${ }^{14}$. However, the Dutch ministries actively and successfully collaborated, jointly drafting policy briefs (e.g. an International Water Ambition in 2016) and setting up a joined "International Water Cluster" for coordination of their international activities. Also, they jointly developed a brochure called "the Delta Approach", in which they summarized the core elements of Dutch delta management and celebrated its international applications (Rijksoverheid, 2014). These activities represent a unified 'policy model' (see Minkman and Van Buuren, 2019) for a description of this policy model). Also, Dutch branding activities emphasized the unity of the variety of stakeholders involved in (international) water management, by consequently referring to "the Dutch Water Sector" (www. dutchwatersector.com), giving credence to the strategic planning ability of the Dutch government as a whole.

Policy tool branding. Currently the German TNE-sector comprises at least six distinct policy tools, such as Bilateral Universities, German Faculties, and German Institutes at foreign partner universities, Centres of Excellence, African Science Service Centres and individual study programmes at partner universities (see Fromm and Raev, 2018). Currently all these projects seem to exist along-side each other as detached and individual higher education projects. In addition, these projects were separately developed and funded by different key state actors, e.g. the Federal Foreign Office, the Federal Ministry of Education and Research and the Federal Ministry for Economic Cooperation and Development (Fromm and Raev, 2018).

Despite their individual successes, German TNE-projects were largely ignored as branding objects. Exceptions were two bilateral TNE-projects, and the so-called Centres of African Excellence. The German-Kazakh University and the German-Mongolian Institute for Resources and Technology were communicated as policy tools in thematic and regional foreign strategies (Auswärtiges Amt, 2009; DAAD, 2017). However, the Bilateral Universities targeted only a very specialized audience in Central Asia and Mongolia.

The Centres of African Excellence, while being independent institutions, were given comparable names and set up with similar internal structures. The brand of these Centres was created by the German Academic Exchange Service. This intermediary organization funded and developed a common website, for which it even developed an own logo. Likewise it oversaw the naming process of the individual centres (DAAD, 2020). Despite these branding activities, the brand visibility remained limited, as the individual Centres did not use the common logo offered by the German Academic Exchange Service, but developed own representative symbols.

Although the German Academic Exchange Service was involved in virtually all German TNE-projects, it was not 
commissioned by the German government to extend these branding activities to other TNE-institutions. This greatly limited the potential and range of the branding efforts in the field of German TNE.

In the Dutch case we also observed a diverse set of policy tools that were branded, however in a much more coherent manner. Example projects were collected in the brochure 'The Delta Approach' and the slogan 'Bring in the Dutch' was embraced to promote the 'Dutch water sector' as a collective (Rijksoverheid, 2014). On the one hand, branded tools were innovations in flood defence, such as the world-famous Delta Works (constructed in the 1970-80s), while other, simultaneously branded tools advocated accommodating water rather than constructing flood defences (e.g. the "Room for the River" projects). Respondents pointed out that sometimes multiple projects under the flag of 'the Dutch Water Sector' can be undertaken in the same country, advocating different and sometimes contrasting tools. These individual projects each had their own logo. This variation somewhat limits the effectiveness of the branding process (see also section "Limitations of the brands").

Purposes of branding. The establishment of German TNEprojects was grounded in the domains of foreign policy, higher education policy and development policy, pursuing varying and partially contradictory policy aims as diverse as cultural exchange, internationalization and migration management, to name just a few (see here Raev, 2017). Over the years the field of German TNE was characterized by a layering of an increasing number of policy aims, reflecting mainly inter-ministerial conflict and failing coordination within the German political system (see here Fromm and Raev, 2018). Hence, the identification of branding purposes in the German field of TNE is closely related to fragmented policy aims. While place branding in the sense of promoting the Science Location Germany and policy tool branding highlighting the success of the Centres of African was clearly discernible, other branding purposes have been either unclearly formulated or not attempted at all, leaving a number of policy aims disconnected from any discernible branding activity.

In comparison, the official rationale for the "DDA" was to increase "water safety and water security in urban deltas and its supply systems, and the Dutch share in achieving this (...)". (Rijksoverheid, 2016, p. 5). As such, the Dutch government not only wanted to assist other countries in their delta management, but also aimed at creating economic opportunities for its domestic water sector, connecting the DDA directly to the 'aid to trade' paradigm. The Dutch government therefore selected mostly transition countries, anticipating a future relationship in which these countries become equal trading partners. However, the Dutch water sector needed a reputation boost as well. The sector was mainly relying on historical achievements. The last major flood in the Netherlands took place in the 1950s and current water management students were born after the "neardisaster" in the late 1990s when the Netherlands barely prevented major dike breaches (Rijksoverheid, 2008). As such, the water sector needed to update its (international) portfolio to re-establish its reputation as providing world-class expertise.

Brand creation. Evaluating the brand creation regarding our two case studies, the German example shows only fragmented branding activities, while the Dutch case professed more promising results. In the German case, branding was largely absent in all three dimensions of possible nation state branding activities. Due to inter-ministerial competition and a resulting inefficient or even absent strategic planning, the German government failed to make use of its TNE-activities as a tool in overarching place- branding activities. At the same time, it failed to create a convincing TNE-policy brand, highlighting its successes in the world. Similarly, individual TNE-projects were only reluctantly used to create policy tool brands, as can be observed in the case of the Centres of African Excellence (DAAD, 2020).

On the other side of the spectrum stands the Dutch case. Here, branding was clearly part of a larger strategic framework and closely tied to political objectives. The branding campaign served the political goal to increase the Dutch role in improving water security and water safety internationally. "Focus deltas" were selected with whom the brand should resonate. Also, as the initial analysis by Minkman and Van Buuren (2019) illustrated, the creation of the brand involved a stakeholder network and sufficient resources were provided to develop and communicate the brand. Only brand maintenance was limited to ad hoc adjustment of procedures and communications.

Limitations of the brands. Taking into consideration the German case, limitations of branding activities became clearly visible. The most important limitation seems to have been the inconsistent integration of the policy field into aligned strategic contexts, agreed upon by the main stakeholders and an ever-growing number of policy aims connected to individual TNE-projects. This fragmentation prevented the development of clear messages or emotional associations to either the sector of TNE as a whole or to different TNE-projects of the same type. A second limitation could be found in the institutional setup of the field. A coordination of branding activities among three competing nation state ministries largely failed. Apart from missing branding aims and the subsequent branding strategies, the current actor arrangement illustrated the absence of an institution that is able to act as a branding manager, i.e. bringing together the various policy aims connected with the establishment of German TNE-projects abroad. Hence, the alignment of names, logos, and slogans, which would have been needed to create viable TNE-brands, never substantiated, leaving the German sector of TNE largely invisible vis-à-vis its competitors.

Although the DDA became a strong brand with congruent associations at the place and policy layers, branding at the policy tool layer was less consistent. Firstly, there was confusion on the side of the targeted countries as to what advantages the DDA approach could provide. Interestingly, the image-reality gap took some time to manifest. Non-Dutch interview respondents that were at the 'receiving end' of the branding campaign expressed their doubts over the "DDA". They perceived the brand as ambiguous at the policy tool layer, pointing out that it both advocated traditional water management, characterized by hard infrastructure, while at the same time advocating for adaptive measures that would allow natural systems to flourish (e.g. BAPA \& BEN, 2019). These inconsistencies were not addressed by the governance structure of the brand. Dutch respondents did not know, who to turn to with their experience and their ideas to improve the policy model (policy brand layer). This lack of updating the brand appeared as a limitation of the branding process. Thus, the uncoordinated brand maintenance also formed a contrast to the highly coordinated activities of Dutch brand creation and of Dutch brand communication in the water sector.

\section{Implications for theory and practice}

In this paper we have introduced a novel framework to understand the use of branding as a tool for SD in its Science For Diplomacy form, given that branding was hitherto overlooked as part of the SD toolbox. The main contribution of this paper is thus the identification of three different layers of branding, i.e. the nation state, the policy, and the policy tool layers, and connecting 
them to the broader field of SD. By comparing the case of German TNE to the example of the DDA we were able to illustrate the usefulness of this framework to explain the effectiveness of $\mathrm{SD}$. Besides this contribution of branding to the toolbox of SDscholars, we draw three key conclusions based on the empirical application of this framework.

First of all, the comparison of branding activities in the fields of German TNE and Dutch DDA suggests, that there is a need for active brand creation and brand management by nation state decision makers as well as for a comprehensive branding coordination. Both are preconditions for a successful use of branding by nation state-level decision makers. As was established before, science, technology, and innovation can serve a multitude of functions, including the improvement of international relations (Gluckman et al., 2017). Branding can be understood as an tool for nation state actors to promote scientific projects, to highlight national innovation, and to project nation state images onto a global stage. However, in order to achieve an effective branding in $\mathrm{SD}$, the coordination of organizations and objectives both within and outside of government is required. Only clearly defined responsibilities and coordinated policy decisions could facilitate a standardized and, hence effective, branding process. Without grounding in strategically sound frameworks, a consistent branding at the policy or policy tool layer seems an almost impossible endeavour. At the same time we saw the need of a brand manager (Eshuis and Klijn, 2012; Govers, 2011), coordinating branding activities, avoiding contradictory branding activities. We thus suggest that the effectiveness of policy tool branding could be increased, if nation state actors harmonized not only their project planning activities, but their branding activities too. Therefore, especially the effects of the use of specific policy tools at all three branding layers within multi-stakeholder diplomacy fields (Hocking, 2006) should be anticipated and monitored more closely, than it is currently done. Interministerial conflicts, regarding the use and the branding of specific policy tools could be defused by assigning an independent brand manager, thereby avoiding contradictory branding activities, while allowing for aligned planning processes going beyond immediate and shortterm policy interests of actors on the domestic level.

Secondly, we conclude that uncoordinated branding campaigns do not only carry the risk of ineffectiveness, but might even harm government's diplomatic endeavours. Charlotte Rungius (2018) already outlined how SD operates in both the scientific and diplomatic arena. This entails, that those engaged in branding science or innovation also influence the diplomatic arena. While the advantages of a successful policy branding are obvious, the consequences of missed branding opportunities or backfiring brand images are less clear, with negative consequences often unequally distributed across the actors involved. When an individual product is unsuccessfully branded (e.g. by failing to deliver the promised results), the nation brand as a whole-and therewith the involved state actors-might be negatively affected as well. Hence, the risk of a deficient branding process at either one of the three supposed branding layers lies mainly at the nation state layer. Since we used only two case studies, our argumentations are bound to contain gaps and missing analytical depth. We see therefore the need for more research to systematize the patterns of benefits and risks to the different actor levels involved in SD-related branding activities.

Thirdly, our study confirms observations of a changing role of Foreign Ministries, other nation state actors and science itself in SD. Non-state actors increasingly play a central role in SD (Stone, 2020). Branding as a tool for SD also brings various non-state actors into the process, as these actors form the 'brand network' that uses and communicates the brand. As such, the role of Foreign Ministries in (Science) Diplomacy will change from sole actors in the field, to that of coordinators and managers of multistakeholder processes. At the same time, branding innovations or science activities for diplomatic or political purposes may contribute to the politicization of science, something deemed undesirable by the scientific community (see e.g. The Royal Society \& AAAS, 2010, p. 16). Hence, branding can be a sensible addition to other activities aiming at improving the efficiency of Science for Diplomacy activities, but should be done so only after careful consideration by nation state actors. To that end, more detailed studies of branding activities and their connection to project funding and project management on the level of Science Diplomats should be undertaken. This would allow to further deepen the understanding of possibilities and limitations that nation states ministries face, when it comes to the branding of their SDrelated activities.

The new perspective on branding, on brand layers and on brand limitations within the field of SD proposed in this paper offers the opportunity for conceptual development of SD studies. By comparing the German TNE case to the Dutch DDA case, our study further offers recommendations to practitioners regarding the need to coordinate branding activities and align branding across the three layers introduced in this study. Nevertheless, our contribution remains limited to just two cases in two different scientific fields. We therefore encourage other researchers to expand the application of our framework to several cases in a single field. Especially global crises, such as the recent COVID-19 pandemic (Šlosarčik et al., 2020) and ensuing instances of national competition (Allen et al., 2020), made the need to better understand branding activities within SD the more important and fascinating. In an era of Brexit, financial upheavals and the global climate crisis, crisis seems to be the 'new normal'. Hence, analyses of how various governments have tried to brand their countries' abilities to fight all kinds of crises give ample empirical material to test and hopefully refine the framework of branding in the realm of SD and the broader Foreign Policy realm. We believe that especially studies to understand the role of branding, diplomacy and reputation management during the recent global Covid-19 crisis (Ślosarčik et al. 2020) poses a relevant endeavour for SD scholars.

\section{Data availability}

The datasets analysed during the current study are not publicly available due to the use of the interviews in other contexts but are available from the corresponding author on reasonable request.

Received: 14 March 2020; Accepted: 29 September 2020;

Published online: 19 October 2020

\section{Notes}

1 For an extensive literature review on the recent Public Diplomacy research, see Auer (2017, pp. 2-3).

2 The issue of new actors engaging in multi-level settings is not restricted to SD, but can be found in all spheres of Public and Cultural Diplomacy (see here Hocking, 2006 and Murray, 2018, p. 5).

3 An increasing senitization "to both diplomatic and foreign policy goals" (Kevany, 2014) regarding responses to various infectious diseases (Šlosarčik et al., 2020), the latest being COVID-19 becomes visible as a "Global Health Diplomacy" (Kevany, 2014). Especially after the outbreak of COVID-19 in early 2020, various nations have been working hard to (im)prove their reputation as leaders in vaccine or drug research (search), but as well in science-based social distancing management (source) and medical gear production (source).

4 A similar definition is given by Grix (2014, p. 14), drawing on the work of Doyle and The American Marketing Association.

5 Brand images can even be hijacked, as happened with the health care reform project under US-President Barack Obama. The Republican Party was able to re-brand the 
policy by naming Obamacare, thus connecting negative associations regarding health care issues directly to the person of the President (see here Cosgrove, 2014).

6 See correspondingly Chou et al. (2017) for a discussion on the multi-level nature of education governance, further complicating the matter.

7 Important tools for place branding to boost the global reputation of a city or country are mega-events like the Soccer World Cup or the Olympic Games (Coaffee, 2013; Grix and Coulihan, 2014).

8 Although we focus our attention mainly on TNE or Water Mangement projects, policy tools come in many forms and can comprise "a dizzying array of loans, loan guarantees, grants, contracts, social regulation, economic regulation, insurance, tax expenditures, vouchers, and much more" (Salamon, 2000, p. 1612), all of which can be branded.

9 For a discussion on different phases of branding processes, see Ogden et al. (2003). For the process of brand development, see Ogden et al. (2003), Basu and Wang (2009), and Eshuis and Klijn (2012)

10 They did so by adding the term 'German' to a number of TNE-projects, especially in the case of bi-national universities, which were called German Universities (see here Raev, 2017, p. 249).

11 We consider the DDA as a science-driven sector based on innovative research.

12 Counter to the domestic higher education sector, where the Laender have competencies over the establishment of new higher education institutions, in the field of TNE they play almost no active role and don't even seem to have veto powers.

13 For a more detailed description of the German TNE sector see Raev (2017) and Fromm and Raev $(2018,2020)$.

14 These ministries are currently called "Economic Affairs \& Climate Change" and "Infrastructure and Water Management". We refer to these ministries with their respective names during brand creation.

\section{References}

Allen J, Burns N, Garret L, Haass R, Ikenberry J, Kishore M, Menon S, Niblett R, Nye J, O’Neil S, Schake K, Walt S (2020). How the world will look after the coronavirus pandemic. The pandemic will change the world forever. We asked 12 leading global thinkers for their predictions. Foreign Policy. https:// foreignpolicy.com/2020/03/20/world-order-after-coroanvirus-pandemic/ Accessed 28 Sep 2020

Auer C (2017) Theorie der Public Diplomacy. Sozialtheoretische Grundlegung einer Form strategischer Kommunikation. Springer VS, Wiesbaden

Ajan B (2015) Branding, legitimation and the power of museums: the case of the Louvre Abu Dhabi. Mus Soc 13(3):316-355. https://doi.org/10.29311/mas. v13i3.333

Altbach PG (2015) Higher education and the WTO: globalization run Amok. Int High Educ 23:2-4. https://doi.org/10.6017/ihe.2001.23.6593

Auswärtiges Amt (2009). Nachhaltigkeit als Aufgabe der internationalen Kulturund Kommunikationspolitik. Auswärtiges Amt, Berlin

Auswärtiges Amt (2013). Ziele der Außenwissenschaftspolitik. http://www. auswaertigesamt.de/DE/Aussenpolitik/KulturDialog/05_Wissenschaft/ UebersichtAWP_node.html. Accessed 18 Aug 2016

BAPA \& BEN (2019). Resolution of the "Special conference on Bangladesh delta plan 2100 and sustainable development in Bangladesh", pp. 1-17. Bangladesh Poribesh Andolon (BAPA) \& Bangladesh Environment Network (BEN), Dhaka

Basu A, Wang J (2009) The role of branding in public health campaigns. J Commun Manag 13(1):77-91. https://doi.org/10.1108/13632540910931409

Berg L-P (2010) Swiss science diplomacy. Politorbis 49(2):69-74

Braun E (2012) Putting city branding into practice. J Brand Manag 19:257-267. https://doi.org/10.1057/bm.2011.55

Chou M, Jungblut J, Ravinet P, Vukasovic M, Jungblut J, Ravinet P, Vukasovic M (2017) Higher education governance and policy: an introduction to multiissue, multi-level and multi-actor dynamics. Policy Soc 4035:1-15. https://doi. org/10.1080/14494035.2017.1287999

Coaffee J (2013) Policy transfer, regeneration legacy and the summer Olympic Games: lessons for London 2012 and beyond. Int J Sport Policy Politics 5 (2):295-311. https://doi.org/10.1080/19406940.2012.693518

Cosgrove K (2014) Personal political branding at state level. In Lees-Mearshment J, Conley B, Cosgrove K (eds) Political marketing in the United States. Routledge, New York, pp. 148-163

Czarniawska B, Joerges B (1996) Travels of ideas. In:Czarniawska B, Sev G (Eds) Translation of orgnizational change. Walter de Gruyter, Berlin, pp. 13-48

DAAD (2012) Transnationale Bildung in Deutschland. Positionspapier des DAAD. Deutscher Akademischer Austauschdiesnst, Bonn

DAAD (2017). Deutsch-Mongolische Hochschule für Rohstoffe und Technologie. https://www2.daad.de/der-daad/daad-aktuell/de/56538-deutschmongolische-hochschule-fuer-rohstoffe-und-technologie-ingenieure-fuerdie-zukunft/. Accessed 28 Sept 2020

DAAD (2020) African excellence. https://www.african-excellence.de. Accessed 28 Sep 2020
DAAD, \& DZHW (2018) Wissenschaft weltoffen 2018. Daten und Fakten zur Internationalität von Studium und Forschung in Deutschland. W. Bertelsmann Verlag, Bielefeld, Deutscher Akademischer Austauschdienst (DAAD), Deutscher Zentrum für Hochschul-und Wissenschaftsforschung

Dinnie K (2016) Nation branding: concepts, issues, practice, 2nd edn, vol. 39. Routledge, Abingdon

Donner M, Horlings L, Fort F, Vellema S (2017) Place branding, embeddedness and endogenous rural development: four European cases. Place Brand Public Dipl 13(4):273-292. https://doi.org/10.1057/s41254-016-0049-z

Drori GS, Delmestri G, Oberg A (2016) The iconography of universities as institutional narratives. High Educ 71(2):163-180. https://doi.org/10.1007/ s10734-015-9894-6

Eshuis J, Klijn E-H (2012) Branding in governance and public management. Routledge, New York

Fähnrich B (2013) Science diplomacy. Strategische Kommunikation in der Auswärtigen Wissenschaftspolitik. Springer VS, Wiesbaden

Flink T, Schreiterer U (2010) Science diplomacy at the intersection of S\&T policies and foreign affairs: toward a typology of national approaches. Sci Public Policy 37:665-677. https://doi.org/10.3152/030234210X12778118264530

Fromm N, Raev A (2018) Contesting contextual forces of national politicsexplaining german transnational education from a policy design perspective. Eur Policy Anal 4(2):275-293. https://doi.org/10.1002/epa2.1042

Fromm N, Raev A (2020) The emergence of transnationalisation of higher education of German universities. In Nickl B, Popenici S, Blackler D (eds) Transnational German education and comparative education systems. Springer Nature Switzerland AG, Cham, pp. 43-62

Gienow-Hecht J (2019) Nation branding: a useful category for international history. Dipl Statecraft 30(4):755-779. https://doi.org/10.1080/09592296.2019.1671000

Gluckman PD, Turekian VC, Grimes RW, Kishi T (2017). Science diplomacy: a pragmatic perspective from the inside. Sci Dipl 6(4). https://www. sciencediplomacy.org/article/2018/pragmatic-perspective. Accessed 27 Sep 2020

Govers R (2011) From place marketing to place branding and back. Place Brand Public Dipl 7(4):227-231. https://doi.org/10.1057/pb.2011.28

Greenwald MB (2018). The new race for contemporary arts dominance in the Middle East. https://www.belfercenter.org/publication/new-race-contemporary-artsdominance-middle-east. Accessed 27 Sep 2020

Grincheva N (2020) Glocal diplomacy of Louvre Abu Dhabi: museum diplomacy on the cross-roads of local, national and global ambitions. Museum Manag Curatorship 35(1):89-105. https://doi.org/10.1080/09647775.2019.1683883

Grix J, Coulihan B (2014) Sport mega-events as part of a nation's soft power strategy: The cases of Germany (2006) and the UK (2012). The British Journal of Politics and International Relations. 2014(16):572-596. https://doi. org/10.1111/1467-856X.12017

Hocking B (2006) Multistakeholder diplomacy: forms, functions and frustrations In: Kurbalija J, Katrandjiev V (Eds.) Multistakeholder diplomacy: forms, functions and frustrations. DiploFoundation, Malta, pp. 13-21

Holland.com. (n.d.). Nederland Waterland. https://www.holland.com/be nl/ toerisme/ontdek-nederland/traditioneel/nederland-waterland-4.htm. Accessed 16 Feb 2020

Jansen SC (2008) Designer nations: neo-liberal nation branding-Brand Estonia. Soc Identities 14(1):121-142. https://doi.org/10.1080/13504630701848721

Kapferer JN (1992) Strategic brand management: creating and sustaining brand equity long term. Kogan Page, London

Kathöfer T (2013) Die Hochschule der Zukunft ist transnational. In Deutscher Akademischer Austauschdienst (ed) Transnationale Bildung. Deutsche und internationale Modelle, Erfahrungen und Ziele. Deutscher Akademischer Austauschdienst, Bonn

Kavaratsis M, Hatch M (2013) The dynamic of place brands: An identity-based approach to place branding theory. Marketing Theory 13(1):69-86. https:// doi.org/10.1177/1470593112467268

Kevany S (2014) Global health diplomacy, 'Smart Power', and the new world order. Global Public Health 9(7):787-807. https://doi.org/10.1080/ 17441692.2014 .921219

Knie A, Simon D (2016) Innovation und Exzellenz: Neue und alte Herausforderungen für das deutsche Wissenschaftssystem. In: Simon K, D., Knie A, Hornbostel S, Zimmermann (Ed.) Handbuch Wissenschaftspolitik, 2nd edn. Springer VS, Wiesbaden

Knight J (2011) Education hubs: a fad, a brand, an innovation? J Stud Int Educ 15 (3):221-240. https://doi.org/10.1177/1028315311398046

König M, König W (2012) Government public option research and consultation: experience in deliberative marketing. In: Lees-Marshment J (Ed.) Routledge handbook of political marketing. Routledge, New York, pp. 48-60

Kwiek M (2013) Knowledge production in European Universities: states, markets, and academic entrepreneurialism. Peter Lang $\mathrm{GmbH}$, Internationaler Verlag der Wissenschaften, Frankfurt am Main

Lynch J, De Chernatony L (2004) The power of emotion: brand communication in business-to-business markets. J Brand Manag 11(5):403-419. https://doi.org/ 10.1057/palgrave.bm.2540185 
Marsh D, Fawcett P (2011) Branding, politics and democracy. Policy Stud 32 (5):515-530. https://doi.org/10.1080/01442872.2011.586498

McCann E (2013) Policy boosterism, policy mobilities, and the extrospective city. Urban Geogr 34(1):5-29. https://doi.org/10.1080/02723638.2013.778627

McCann E, Ward K (2014) Exploring urban policy mobilities: the case of business improvement districts. Sociologica 8(1). https://doi.org/10.2383/77048

Minkman E, Van Buuren A (2019) Branding in Policy Translation: how the Dutch Delta Approach became an international brand. Environ Sci Policy 96:114-122. https://doi.org/10.1016/j.envsci.2019.03.005

Mohammadzadeh B (2017) Status and foreign policy change in small states: Qatar's emergence in perspective. Int Spectator 52(2):19-36. https://doi.org/10.1080/ 03932729.2017 .1298886

Murray S (2018) Sports diplomacy. Origins, theory and practice, 1st edn. Routledge

Nye JSJ (2004) Soft power: the means to success in world politics. Public Affairs. https://doi.org/10.1016/S0277-9536(02)00373-8

Ogden J, Walt G, Lush L (2003) The politics of 'branding' in policy transfer: the case of DOTS for tuberculosis control. Soc Sci Med 57(1):179-188. https:// doi.org/10.1016/s0277-9536(02)00373-8

Papadimitriou A, Gornitzka Å, Stensaker B (2015) Designed diffusion? The impact of an EU instrument for public management reform in the Western Balkans. J Eur Integr 37(6):629-647. https://doi.org/10.1080/07036337.2015.1046857

Penca J (2018) The rhetoric of "science diplomacy": innovation for the EU's scientific cooperation? EL-CSID Working Paper Issue, University of Pittsburgh, Pittsburgh, 2018/16, 1-16. http://aei.pitt.edu/102624/1/2018.16.pdf. Accessed 25 Sep 2020

Raev A (2017) Institutionelle Arrangements einer politisierten transnationalen Hochschulbildung vis-à-vis globaler Wissensmärkte: das Beispiel Deutschlands. In: Schmid J, Amos K, Schrader J, Thiel A (Eds.) Governance und Interdependenz von Bildung. Internationale Studien und Vergleiche. Nomos Verlagsgesellschaft, Baden-Baden, pp. 245-271

Rijksoverheid (2008) Nationaal Waterplan 2009-2015 [National Water Plan 2009-2015]. http://publicaties.minienm.nl/documenten/national-water-plan2009-2015. Accessed 27 Sept 2020

Rijksoverheid (2014) The Delta approach. Den Haag, the Netherlands. https:// issuu.com/ruimtevoorderivier/docs/uitgave_tijdens_dip_-_140209-01_del. Accessed 27 Sep 2020

Rijksoverheid (2016) Convergerende stromen-Internationale waterambitie [Converging flows-International Water Ambition]. https://www.tweedekamer.nl/ kamerstukken/brieven_regering/detail?id=2016Z02209\&did=2016D04593. Accessed 9 Oct 2020

Rijksoverheid (2018) Netherlands as Water Land takes the stage at UN on World Water Day. https://www.rijksoverheid.nl/actueel/nieuws/2018/03/18/ nederland-waterland-pakt-podium-bij-de-vn-op-wereldwaterdag. Accessed 27 Sep 2020

Rungius C (2018) State-of-the-art report: summarizing literature on science diplomacy cases and concepts. Report by Science for/in Diplomacy for Addressing Global Challenges. Available via S4d4C project website: https:// www.s4d4c.eu/wp-content/uploads/2018/08/S4D4C_State-of-theArt_Report_DZHW.pdf. Accessed 25 Sep 2020

Salamon LM (2000) The new governance and the tools of public action: an introduction. Fordham Urban Law J 28(5):1-47

Schulze-Cleven T, Olson JR (2017) Worlds of higher education transformed: toward varieties of academic capitalism. High Educ 73(6):813-831. https:// doi.org/10.1007/s10734-017-0123-3

Schütte G (2008) Wettlauf ums Wissen: Außenwissenschaftspolitik als Herausforderung moderner Wissensgesellschaften. Eine Einführung. In: Schütte G (Ed.) Wettlauf ums Wissen. Außenwissenschaftspolitik im Zeitalter der Wissensrevolution. Berlin University Press, Berlin, pp. 12-26

Šlosarčik I, Meyer N, Chubb J (2020) Science diplomacy as a means to tackle infectious diseases: the case of Zika. S4D4C. In Young M, Flink T, Dall E (eds) (2020): Science diplomacy in the making: case-based insights from the S4D4C project. Available at S4D4C project website: https://www.s4d4c.eu/ wp-content/uploads/2020/03/D3.2_1_Infectious_Diseases_final.pdf. Accessed 25 Sep 2020

Speed R, Butler P, Collins N (2015) Human branding in political marketing: applying contemporary branding thought to political parties and their leaders. J Political Market 14:129-151. https://doi.org/10.1080/15377857.2014.990833

Stone D (2020) Making global policy, vol. 21. Cambridge University Press, Cambridge
Szondi G (2008) Public diplomacy and nation branding: conceptual similarities and differences. In Discussion papers in diplomacy. Netherlands Institute of International Relations Clingendael, pp. 1-42

Temporal P (2015) Branding for the public sector. creating, building and managing brands people will value. Wiley, Chichester

The Royal Society, \& AAAS. (2010) New frontiers in science diplomacy. https:// royalsociety.org/ /media/Royal_Society_Content/policy/publications/2010/ 4294969468.pdf. Accessed 27 Sept 2020

Topsector Water (2013) Water verdient het. Advies Topsector Water [Water deserves it. Advice top sector water]. https://maritimetechnology.nl/waterverdient-het/. Accessed 27 Sept 2020

Tourekian C, Macindoe S, Copeland D, Davis L, Patman R, Pozza M (2014) The emergence of science diplomacy. In Davis L, Patman R (eds), Science diplomacy. New day of false dawn? World Scientific Publishing Co. Pte Ltd., Singapore, pp. 3-24

Turekian V (2018) The evolution of science diplomacy. Glob Policy 9:5-7. https:// doi.org/10.1111/1758-5899.12622

van Genderen R, Rood J (2011) Water diplomacy: a niche for the Netherlands? Netherlands Institute of International Relations 'Clingendael'. https://www. clingendael.org/sites/default/files/pdfs/

20111200_cling_report_waterdiplomacy_rgenderen_jrood.pdf. Accessed 25 Sep 2020

White J, Chernatony L de (2002) New Labour: A strategy of the creation, development and demise of a political brand. J Political Market. 1(2-3):45-52. https://doi.org/10.1300/J199v01n02_04

Zenker S, Braun E (2017) Questioning a "one size fits all” city brand. J Place Manag Dev 10(3):270-287. https://doi.org/10.1108/JPMD-04-2016-0018

Ziguras C, McBurnie G (2015) Governing cross-border higher education. Routledge, London

\section{Acknowledgements}

We acknowledge support by Open Access Publishing Fund of University of Tübingen and the TU Delft Open Access Fund.

\section{Funding}

Open Access funding enabled and organized by Projekt DEAL.

\section{Competing interests}

The authors declare no competing interests.

\section{Additional information}

Correspondence and requests for materials should be addressed to A.R.; or E.M.

Reprints and permission information is available at http://www.nature.com/reprints

Publisher's note Springer Nature remains neutral with regard to jurisdictional claims in published maps and institutional affiliations.

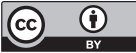

Open Access This article is licensed under a Creative Commons Attribution 4.0 International License, which permits use, sharing, adaptation, distribution and reproduction in any medium or format, as long as you give appropriate credit to the original author(s) and the source, provide a link to the Creative Commons license, and indicate if changes were made. The images or other third party material in this article are included in the article's Creative Commons license, unless indicated otherwise in a credit line to the material. If material is not included in the article's Creative Commons license and your intended use is not permitted by statutory regulation or exceeds the permitted use, you will need to obtain permission directly from the copyright holder. To view a copy of this license, visit http://creativecommons.org/ licenses/by/4.0/.

(C) The Author(s) 2020 